\title{
IMPLEMENTASI PENILAIAN AUTENTIK DALAM KURIKULUM 2013
}

\author{
Fadhillah Millah Abdillah, Sulton, Arafah Husna \\ Jurusan Teknologi Pendidikan, Fakultas Ilmu Pendidikan, Universitas Negeri Malang \\ Jalan Semarang 5 Malang 65145 0341-574700 \\ Fadhillahmillah30@gmail.com
}

Article History

Received: 27 Juni 2020, Accepted: 3 September 2020, Published: 26 Februari 2021

\begin{abstract}
Abstrak
Penelitian ini bertujuan mendeskripsikan implementasi penilaian autentik dalam kurikulum 2013 pada jenjang SMP baik di sekolah negeri maupun sekolah swasta. Metode penelitian yang dilakukan menggunakan pendekatan kualitatif yang bersifat deskriptif. Berdasarkan hasil penelitian yang telah dilaksanakan didapatkan data secara keseluruhan pada ketiga aspek penilaian bahwa pengajar sudah mengetahui secara teori tentang penilaian autentik, para pengajar juga memahami dengan baik penilaian autentik beserta cara merencanakan penilaian autentik hingga pelaksanaannya. Tetapi masih ada beberapa pengajar yang dalam proses perencanaan dan pelaksanaan hanya melakukan seadanya tanpa mematuhi rambu-rambu yang berlaku pada penilaian autentik. Para pengajar juga mengatakan bahwa banyak kendala yang dihadapi dalam proses implementasi penilaian autentik, salah satunya adalah banyaknya jumlah anak didik sehingga proses pengambilan nilai pada aspek sikap dan keterampilan hanya seadanya. Oleh karena itu, para pengajar perlu memperhatikan dengan seksama rambu-rambu dalam melaksanakan penilaian autentik baik pada aspek sikap, pengetahuan, dan keterampilan.
\end{abstract}

Keyword: Penilaian Autentik; Kurikulum 2013.

\begin{abstract}
This study aims to describe the implementation of authentic assessment in the 2013 curriculum at junior high level in both public and private schools. The research method used is descriptive qualitative approach. Based on the results of research that has been done, the researcher obtained overall data on the three aspects of assessment that teachers already understood the theory of authentic assessment. The teachers also comprehended the authentic assessment and how to plan authentic assessment well. However, there were some teachers who only did what they could do without adhering to the rules which applied to authentic assessment. The teachers mentioned that there were many obstacles encountered in the process of implementing authentic assessment, one of which was the large number of students that resulted in the process of taking scores on aspects of attitudes and skills only on the surface. Therefore, teachers need to carefully interpret the rules in carrying out authentic assessments covering in the aspects of attitude, knowledge, and skills.
\end{abstract}

Keyword: Authentic Assessment; Curriculum 2013. 


\section{PENDAHULUAN}

Saat kini Indonesia menjalankan Kurikulum 2013, yang asal mula kurikulumnya berawal dari KBK atau Kurikulum Berbasis Kompetensi. Menurut Poerwati dan Sofan Amri (2013:28) Kurikulum 2013 yakni kurikulum yang terintegrasi, yang didefinisikan dengan terintegrasi adalah kurikulum yang mampu mengintegrasikan antara skill, themes, concepts, dan topics pada bentuk within single diciplines, across several diciplines, dan within and across learners. Kurikulum yang ditafsirkan yaitu kurikulum sistematis sebagai konsep dari sebuah metode atau prosedur pengkajian yang mengikutsertakan sejumlah disiplin ilmu/bidang keahlian yang berguna menyampaikan wawasan dan pengalaman luas serta bermakna terhadap para pelajar, jadi sistem kurikulum 2013 lebih mengedepankan pada kolaborasi antara guru dengan pelajar dalam edukasi hingga berhasil memecahkan suatu masalah bersama-sama.

Kurikulum 2013 memadukan tiga pokok yang menyeimbangkan yaitu attitude, skill, dan knowledge. Melalui ketiga pokok tersebut kesimbangan antara hard skill yang diawali dari Standar Isi, Standar Proses, Standar Kompetensi Lulusan, dan Standar Penilaian berhasil diwujudkan (Rahman \& Romdhani, 2015). Berdasarkan Ermawati \& Hidayat (2017) Penilaian pembelajaran seharusnya dijalankan dengan mendalam, mencakup semua ranah dari pengetahuan, keterampilan hingga sikap. Evaluasi seharusnya juga memfokuskan pada prosedur pembelajaran hingga perolehan pembelajaran. Instrument yang mampu difungsikan dalam melangsungkan penilaian pembelajaran bisa berwujud tes ataupun non tes (Ristanto \& Djamahar, 2019). Pada kurikulum 2013 penilaian autentik menjadi syarat rujukan bagi pengajar untuk mengevaluasi perolehan belajar para siswa. Proses edukasi dan evaluasi yang dikerjakan dengan terintegrasi secara baik dapat mengelaborasi kemampuan para pelajar hingga cakap membentuk insan-insan terdidik, berkarakter, berprestasi dan mempunyai kapabilitas yang diperlukan pada era ini. Pengajar juga diharapkan mampu mentrasnformasikan kemampuankemampuan pada pelajar melalui sistem perencanaan, pelaksanaan, hingga evaluasi edukasi secara efisien dan efektif.

Penilaian autentik diidentikkan dengan evaluasi yang berlandaskan keadaan nyata, dan langsung, yang berfokus pada edukasi aktif dan perhitungan yang tidak selalu tetap namun memiliki tolak ukur yang jelas (Wajdi, 2017). Penelitian-penelitian yang sudah pernah dilaksanakan sebelumnya lebih kerap difokuskan pada evaluasi satu kompetensi, seperti penelitian yang dikerjakan sekadar melihat kompetensi keterampilan saja. Penelitian yang dikerjakan pada penilaian autentik lebih sering berdasar pada hasil belajar pelajar saja. Berdasarkan hal tersebut, penelitian ini dibuat untuk memperluas jangkauan authentic assessment yang dijalankan oleh pengajar. Penilaian autentik tidak semata-mata menilai hasil belajar pelajar, tetapi berupa kesibukan yang dirasakan oleh pelajar saat menerima dan mengimplementasikan pembelajaran saat di dalam kelas bahkan di luar kelas. Standar tentang penilaian autentik sendiri mencakup bidang kognitif, afektif, dan psikomotorik. Penilaian autentik lebih mencermati keteraturan antara evaluasi pada kompetensi keterampilan, kompetensi sikap, dan kompetensi pengetahuan yang disesuaikan dengan progress khusus pelajar sinkron dengan tingkatannya (Kunandar, 2015:37).

Penilaian autentik meskipun sesuai dan sangat baik untuk dimanfaatkan dalam mengevaluasi keahlian pelajar terpenting pada ranah keterampilan, melainkan semua pendidik belum memahami tentang mengimplementasikan penilaian autentik dengan akurat dan baik, sehingga siswa kurang terpacu untuk belajar. Hal yang kerap dikeluh kesahkan oleh pengajar mengenai wawasan tentang KI atau Kompetensi Inti dan KD atau Kompetensi Dasar. Pendidik juga kesusahan dalam teknik pembelajaran dan proses penilaian, sehingga wawasan penilaian autentik hanya semata-mata dimengerti, untuk penerapan dan mencocokkan dengan Kurikulum 2013 masih ramai timbul kerancuan (Kusmijati, 2014). Para pendidik sudah berusaha dengan sangat keras untuk mempersembahkan skor yang sebanding dengan kecakapan dan keadaan pelajar di sekolah. Salah satu hambatan yang dirasakan 
oleh pengajar adalah dalam memberikan penilaian, pengajar memiliki referensi pengukuran yang terbatas (Meliana et al., 2019).

Bermula dari munculnya permasalahan-permasalahan tersebut maka dilakukannya penelitian dengan sasaran memahami apakah implementasi penilaian autentik pada kurikulum 2013 di sekolah swasta maupun sekolah negeri sudah berlangsung dengan benar dan baik. Hingga didapatkan data tentang implementasi penilaian autentik yang meliputi perencanaan, pelaksanaan, hingga kendala yang dirasakan oleh para pengajar. Berdasarkan hasil peninjauan awal yang telah dikerjakan di SMP Wahid Hasyim dan SMP Negeri 4 Malang, diketahui bahwa pada SMP Wahid Hasyim yang mencorakkan salah satu sekolah swasta yang baru mengaplikasikan kurikulum 2013 kurang lebih pada 3 tahun terakhir ini. Sedangkan SMP Negeri 4 Malang sudah menyelenggarakan kurikulum 2013 sejak awal ditetapkannya kurikulum 2013. Pada SMP Wahid Hasyim permasalahan yang timbul dalam penyelenggaraan kurikulum 2013 adalah kurangnya sosialisasi guru, sarana dan prasarana yang kurang, serta penyediaan buku yang terlambat tidak serasi agenda yang usai di tentukan. Pada standar penilaian, sebagian pendidik masih kebingungan dengan kebijakan penilaian yang sekarang yang memprioritaskan penilaian autentik.

SMP Negeri 4 Malang mencorakkan salah satu sekolah acuan dari pemerintah, sebagian pengajar yang mengampu dan mendidik di sekolah ini sebagai pelatih atau tutor dalam beragam pelatihan atau bimbingan teknis terkait kurikulum 2013. Setelah melangsungkan observasi awal dan wawancara sebagai sesi akumulasi data awal, para pengajar di SMP Negeri 4 Malang sudah memahami terkait persepsi penilaian autentik. Tetapi, masih ramai pengajar yang mengeluh tentang kendala-kendala yang dihadapi dalam prosedur penilaian autentik. Berdasarkan hasil pengamatan tersebut masih banyak pendidik yang belum memahami terkait penilaian autentik, masih adanya kebingungan dan kerancuan diantara para guru, serta kendala-kendala yang dirasakan para pendidik. Berdasarkan itu, masih perlu adanya kajian ulang mengenai sejauh apakah penilaian autentik sudah berjalan baik di sekolah, serta bagaimana persepsi para pengajar terhadap perencanaan, pelaksanaan, dan kendala yang dihadapi dalam implementasi yang dilangsungkan pengajar pada penilaian autentik. Sehingga hasil penelitian ini dimaksudkan mampu menjadi bahan mawas diri bagi guru, bagi sekolah, maupun bagi pemerintah.

\section{METODE}

Penelitian ini mendeskripsikan tentang implementasi penilaian autentik dalam kurikulum 2013. Berdasarkan tinjauan jenis datanya pelaksanaan penelitian memakai pendekatan kualitatif. Penelitian yang dikerjakan menggunakan metode penelitian kualitatif deskriptif, karena data yang dihasilkan dan dihimpun berupa kata-kata, gambar, dan bukan merupakan angka-angka. Data yang ada dihasilkan dari observasi, angket terbuka, wawancara, dokumentasi, dan catatan lapangan, yang ditelaah secara obyektif, kemudian disajikan dalam susunan narasi deskriptif. Berdasarkan penjabaran tersebut mengenai pendekatan dan ragam penelitian yang telah dilaksanakan dengan judul Implementasi Penilaian Autentik Dalam Kurikulum 2013, yaitu penelitian kualitatif yang bersifat deskriptif yang berguna untuk meneliti, mendeskripsikan, serta memaparkan fenomena-fenomena yang terjadi di SMP Wahid Hasyim dan SMP Negeri 4 Malang mengenai implementasi penilaian autentik dalam kurikulum 2013.

Kehadiran peneliti dalam penelitian kualitatif deskriptif bersifat mutlak, dikarenakan posisi peneliti yang krusial dalam kegiatan penelitian kulitatif deskriptif. Bersangkutan dengan penelitian kuliatatif tersebut, kehadiran peneliti di lapangan berguna sebagai observer. Peneliti berperan melakukan wawancara, dokumentasi, serta penyebaran angket terhadap narasumber yang berkaitan dan menghimpun data sebanyak mungkin guna menguatkan hasil penelitian. Pokok bahasan dalam wawancara, dokumentasi, dan angket yang disebarkan dalam penelitian ini adalah tentang implementasi penilaian autentik dalam kurikulum 2013 di SMP Wahid Hasyim dan SMP Negeri 4 Malang. Penelitian dilakukan pada semester genap tahun ajaran 2019/2020. 
Subjek penelitian ini diseleksi memakai teknik purposive sampling. Pengambilan sampel memakai teknik ini disebabkan tidak seluruh sample memiliki kriteria yang akan diteliti. Kriteria yang dibutuhkan untuk penelitian terbagi menjadi 3 hal (1) Pengajar yang mengampu bidang pelajaran umum, (2) Pengajar yang telah dan sedang melakukan pembelajaran dengan kurikulum 2013, dan (3) Pengajar yang telah dan sedang melaksanakan penilaian autentik. Subyek penelitian ini meliputi guru mata pelajaran umum (IPA, IPS, Matematika, dan Bahasa Indonesia) VII,VIII, dan IX Tahun Ajaran 2019/2020 pada semester genap di SMP Wahid Hasyim yang berjumlah 8 orang disetiap sekolah dengan rincian setiap bidang pelajaran umum diambil 2 orang sebagai narasumber, sedangkan untuk SMP Negeri 4 Malang berjumlah 3 orang pengajar yang terdiri dari 2 orang pengajar bidang pelajaran Matematika dan 1 orang pengajar mengampu bidang pelajaran IPS.

Pengecekan keabsahan data ini mampu dilaksanakan dengan triangulasi (gabungan) yaitu mencari dan melihat validitas dari beragam sisi (dari tiga sudut pandang). Dalam fase ini, dibuat hipotesis yang terikat dengan dasar logika, membahasnya sebagai temuan penelitian, kemudian diteruskan dengan meninjaui secara berulang-ulang data yang ada, dan mengelompokkan data yang ada. Hal yang dapat dilaksanakan dengan cara, membandingkan sesuatu yang dibicarakan didepan umum dengan yang dibicarakan secara pribadi, membandingkan hasil observasi dengan hasil wawancara, membandingkan hasil wawancara dengan hasil angket, serta membandingkan hasil wawancara dengan isi dari suatu manuskrip yang berkaitan. Dalam mengerjakan proses triangulasi data bukan saja persamaan yang dicari tetapi perbedaan juga dapat menjadi alasan tersendiri.

\section{HASIL}

Bersumber dari hasil persepsi dari para narasumber mengenai implementasi penilaian autentik dalam Kurikulum 2013 yang diselenggarakan di SMP didapatkan temuan sebagai berikut.

\section{Pengertian Penilaian Autentik}

Pengertian mengenai penilaian autentik menurut para pendidk adalah penilaian yang dikerjakan dalam menilai pembelajaran pebelajar yang selaras dengan realitas yang menyangkut aspek sikap, pengetahuan, dan keterampilan, yang tidak hanya mengacu pada nilai tetapi juga pada pribadi anak didik, yang memungkinkan pebelajar dapat mendemonstrasikan kemampuannya dalam menyelesaikan masalah-masalah dalam kehidupan dan tugas-tugas di sekolah, sehingga penilaian tidak hanya berdasarkan pada nilai tes maupun ujian saja, tetapi juga berdasarkan kompetensi-kompetensi yang dipunyai pebelajar.

\section{Tujuan dan Ciri-Ciri Penilaian Autentik}

Bersumber dari hasil survei kepada para narasumber didapatkan data bahwa tujuan dari penilaian autentik adalah untuk mengetahui soft skill dan hard skill yang dimiliki oleh anak didik, untuk mengelaborasi kapabilitas pebelajar, untuk mengetahui jenjang pemahaman atau kapabilitas pebelajar serta dapat meningkatkan kualitas dalam prosedur pembelajaran, untuk mengerjakan penilaian secara menyeluruh pada aspek pengetahuan, sikap, dan keterampilan, serta menentukan kebutuhan belajar anak didik. Ciri-ciri penilaian autentik menurut para narasumber adalah pengukuran yang diamati dari beragam aspek, pengukuran yang dikerjakan berlangsung sepanjang proses KBM (Kegiatan Belajar Mengajar) hingga sesudah proses KBM terjadi, dan penilaian autentik ini pengukuran yang dikerjakan lebih kepada implementasi pebelajar terhadap lingkungannya. Penilaian yang dikerjakan secara kontinu dan penilaian ditekankan pada pengetahuan, sikap, dan keterampilan, bukan sekedar kuantitas belaka, serta penilaian yang selaku keseluruhan menggambarkan atau merefleksikan kompetensi sikap, pengetahuan, dan keterampilan.

\section{Ruang Lingkup Penilaian Autentik}

Ruang lingkup pada penilaian autentik terbagi menjadi 3 aspek atau 3 kompetensi yaitu sikap, pengetahuan, keterampilan. 


\section{Perumusan KD dan Indikator dalam RPP}

Sebelum pembelajaran dilaksanakan guru diwajibkan menyiapkan dan membuat RPP (Rencana Pelaksanaan Pembelajaran) yang disesuaikan berlandaskan silabus yang sudah ada sesuai dengan bidang pelajaran yang diampu. Dalam RPP ada Kompetensi Dasar atau bisa disebut KD dan Indikator yang perlu dirumuskan. Indikator dalam RPP dirumuskan berdasarkan Kompetensi Dasar yang sudah ada, memakai kata kerja sehingga dapat diukur secara nyata, dirumuskan menggunakan kata-kata yang sederhana atau yang mudah dimengerti agar pembelajaran yang diinginkan dapat terlaksana dengan baik, serta tetap memperhatikan kebutuhan pebelajar dan sekolah. Setiap tahun silabus dan RPP selalu diperbarui dan disinkron dengan kondisi saat ini dan keahlian anak didik.

\section{Keterkaitan antara KD dan Indikator dengan Penilaian Autentik dalam RPP}

Dalam RPP ada koherensi erat antara KD dan Indikator dengan penilaian autentik. Indikator dan KD yang ada pada RPP merupakan penunjang penilaian atau sebagai landasan dalam membentuk indikator-indikator dalam instrumen penilaian autentik yang melingkupi 3 aspek yaitu, sikap, pengetahuan, dan keterampilan.

\section{Kesesuaian Indikator dengan Penilaian Autentik dalam RPP}

Indikator yang ada pada RPP dirumuskan memakai kata kerja yang dapat diukur, maka hal tersebut menjadi sangat uatama agar dapat disinkronkan dengan tujuan yang ada pada penilaian autentik. Indikator-indikator yang ada pada instrumen penilaian didapatkan dari rumusan Indikator yang ada pada RPP.

\section{Penyusunan Instrumen dan Rubrik Penilaian Autentik pada Kompetensi Sikap, Pengetahuan, dan Keterampilan}

Bersumber dari hasil survei kepada para guru, yang dirasakan ketika membuat instrumen dan rubrik penilaian pada kompetensi sikap yaitu menetapkan kompetensi-kompetensi yang akan diraih (meliputi observasi, penilaian diri, penilaian teman sejawat, jurnal, dan wawancara), menyusun indikator, menyusun kriteria ke dalam rubrik, menyusun rubrik, dan instrumen penilaian sikap, serta menyusun batas standar minimal capaian kompetensi atau penskoran. Langkah-langkah yang dikerjakan oleh para narasumber dalam membuat instrumen dan rubrik penilaian autentik pada kompetensi pengetahuan dilaksanakan dengan menetapkan kompetensi (meliputi tes tulis, tes lisan, dan penugasan atau proyek), membuat indikator-indikator, menyusun kriteria, menyusun rubrik, membuat kisi-kisi soal, menyusun soal-soal beserta bobot soalnya, kunci jawaban soal, dan membuat standar minimal dari penilaian. Prosedur pengerjaan instrumen dan rubrik penilaian autentik pada kompetensi keterampilan yang dikerjakan oleh para narasumber adalah menetapkan kompetensi (meliputi penilaian kinerja, penilaian proyek, penilaian produk, dan penilaian portofolio), menyusun indikator, menyusun kriteria, menyusun rubrik, dan membuat tugas-tugas, serta menyusun standar minimal penilaian.

\section{Pelaksanaan Penilaian Autentik pada Kompetensi Sikap, Pengetahuan, dan Keterampilan}

Penerapan penilaian autentik pada kompetensi sikap yang diterapkan oleh para narasumber beradasarkan hasil survei ditemukan bahwa dapat diaplikasikan secara langsung maupun tidak langsung, baik ketika didalam kelas maupun diluar kelas. Diterapkan secara langsung adalah dengan pengajar melakukan observasi maupun wawancara, sedangkan jika diterapkan secara tidak langsung penilaian kompetensi sikap dengan menerapkan penilaian teman sejawat. Pelaksanaan penilaian autentik pada kompetensi sikap yang meliputi observasi diterapkan dengan 1 penilaian untuk $1 \mathrm{KD}$, sedangkan untuk penilaian diri, penilaian teman sejawat, jurnal dan wawancara diterapkan dengan 1 tugas dalam 1 semester. Pada penerapan penilaian autentik pada kompetensi pengetahuan yang diterapkan adalah mengambil nilai bersumber pada hasil penugasan, Ujian Harian, Ujian Tengah Semester, Ujian Akhir Semester, tes-tes yang lain, atau bisa dengan sekedar sesi tanya jawab. Pertama, tes tulis diterapkan dengan ulangan harian, soal, maupun kuis-kuis. Kedua, penugasan diterapkan dengan tugas-tugas yang dikerjakan di rumah. Ketiga, proyek diterapkan di rumah dalam waktu tertentu. Pelaksanaan penilaian 
autentik kompetensi pengetahuan diterapkan dengan menyesuaikan alokasi waktu pertemuan dan banyaknya materi yang telah dikuasai oleh siswa, dalam 4 kali pertemuan bisa dilaksanakan 1 kali tes tulis. Sedangkan untuk tes lisan diterapkan pada saat KBM berlangsung. Pengamalan penilaian autentik pada kompetensi keterampilan, pelaksanaan penilaian yang melingkupi penilaian kinerja, penilaian proyek, penilaian produk, dan penilaian porofolio dilakukan dari format tertulis hingga diperoleh nilai sangat baik, baik, dan cukup. Penilaian tersebut diterapkan bersumber pada tugas-tugas pebelajar yang sinkron dengan instrumen penilaian yang telah dibuat.

\section{Kendala yang dihadapi Guru dalam Penilaian Autentik pada Kompetensi Sikap, Pengetahuan, dan Keterampilan}

Kendala yang dirasakan oleh para narasumber ketika mengimplementasikan penilaian autentik dalam kompetensi sikap adalah kurangnya keterbukaan siswa ketika dilakukan sesi wawancara dan penilaian teman sejawat, waktu dalam mengaplikasikan penilaian yang kurang, kurangnya sarana dan prasarana yang layak untuk memudahkan guru mengakses dan mengaplikasikan penilaian autentik, kapabilitas pengajar yang minim dalam mengamati setiap pebelajar dalam waktu bersamaan dikarenakan jumlah pebelajar yang banyak, serta kendala ketika membuat rubrik penilaian. Pada implementasi penilaian autentik kompetensi pengetahuan kendala yang dirasakan oleh para pengajar adalah kurangnya antusias pebelajar dalam belajar, perlu banyaknya waktu dalam pengerjaan kisi-kisi soal maupun ketika penilaian, hasil atau nilai yang didapatkan pebelajar tidak sinkron dengan kemampuan pebelajar, sebab ada banyaknya kebijakan-kebijakan tambahan dari sekolah, serta kondisi yang dirasakan pebelajar dalam belajar ketika menginterpretasikan materi dengan daya penyerapan setiap pebelajar berbeda-beda. Kendala yang dirasakan oleh para pebelajar dalam implementasi penilaian autentik pada kompetensi keterampilan yaitu kurangnya ketersediaan pebelajar untuk mengamalkan tugas-tugas yang diberikan, kurangnya waktu dan alokasi biaya yang kurang dalam pembuatan format penilaian dan pada proses pelaksanaan, cukup sulit untuk membangun indikator untuk instrumen penilaian keterampilan, perlunya subjektivitas pendidik dalam menilai keterampilan para pebelajar, serta setiap pebelajar memiliki kapabilitas yang berbeda-beda, sehingga saat proses pembelajaran perlu kontrol secara intens untuk memahami hasil pencapaian dari setiap anak didik.

\section{PEMBAHASAN}

Penelitian yang telah dilaksanakan memiliki tujuan guna mengetahui bagaimana proses implementasi penilaian autentik pada kurikulum 2013 di tingkat SMP berlangsung. Penelitian yang dilakukan mencakup 3 aspek mengenai implementasi penilaian autentik, yaitu perencanaan penilaian autentik, pelaksanaan penilaian autentik, dan kendala yang dihadapi oleh para guru dalam implementasi penilaian autentik. Penilaian dalam Kurikulum 2013 yang mengacu pada Permendikbud Nomor 66 Tahun 2013 tentang Standar Penilaian Pendidikan. Standar Penilaian Pendidikan memiliki tujuan untuk menjamin 3 hal dasar yaitu (1) Dalam perancangan penilaian pebelajar dicocokkan dengan kompetensikompetensi yang akan dicapai dan berlandaskan dasar-dasar penilaian, (2) Pelaksanaan penilaian pebelajar dilakukan secara kompeten, gamblang, edukatif, efisien, efektif, serta sesuai dengan kondisi sosial budaya, dan (3) Pelaporan hasil penilaian pebelajar harus secara objektif, akuntabel, dan informatif.

\section{Perencanaan Penilaian Autentik}

Seorang pengajar yang baik sebelum menerapkan pembelajaran harus menyusun perencanaan pembelajaran baik di kelas maupun diluar kelas. Prosedur edukasi yang baik harus diawali dengan permulaan yang matang dan baik, tanpa persiapan akan sulit menerapkan edukasi yang sesuai. Pada umumnya banyak ditemukan pengajar yang membentuk instrumen penilaian sesaat sebelum penilaian akan dilaksanakan. Seharusnya pengajar telah mempersiapkan seluruh perencanaan dalam prosedur pembelajaran termasuk membentuk instrumen penilaian sebelum aktivitas edukasi dilaksanakan (Wildan, 2017). Berdasarkan hasil wawancara yang dilakukan kepada salah satu narasumber menyampaikan bahwa pada sebuah perumusan RPP terdapat Indikator dan KD, KD didasarkan dari 
Kompetensi Inti atau KI. KD diuraikan dalam bentuk Indikator yang terdapat pada RPP, secara keseluruhan KD dan Indikator tidak dapat berdiri sendiri dalam sebuah RPP (N2/Gr/P1-IPA4). Menurut Permendikbud Nomor 65 Tahun 2013 tentang Standar Proses Pendidikan Dasar dan Menengah adalah rangka aktivitas edukasi tatap muka untuk satu pertemuan atau lebih. RPP dikembangkan berdasarkan dari silabus yang dipakai untuk memfokuskan aktivitas edukasi pebelajar dalam upaya mencapai KD.

Menurut Permendikbud Nomor 68 Tahun 2013 tentang Kerangka Dasar dan Struktur Kurikulum Sekolah Menengah Pertama/Madrasah Tsanawiyah bahwa Kompetensi Dasar atau KD dirumuskan untuk mencapai Kompetensi Inti atau KI. Rumusan KD dibuat dengan memperhatikan keistimewaan siswa, kemampuan awal, serta ciri dari suatu mata pelajaran. KD dibagi menjadi empat kelompok sesuai dengan pengelompokkan KI yaitu (1) Kelompok 1: kelompok KD sikap spiritual dalam bentuk memaparkan KI-1, (2) Kelompok 2: kelompok KD sikap sosial dalam bentuk memaparkan KI-2, (3) Kelompok 3: kelompok KD pengetahuan dalam bentuk memaparkan KI-3, dan (4) Kelompok 4: kelompok KD keterampilan dalam bentuk memaparkan KI-4.

Untuk mengamalkan penilaian yang baik ada acuan yang harus diraih dalam merencanakan penilaian. Menurut Kunandar (2015:73) pendidik harus mengelaborasi rencana penilaian secara sistematis yang berlandaskan pada silabus dan RPP. Perencanaan penilaian setidaknya meliputi 3 hal dasar yaitu komponen yang akan dinilai, teknik yang akan dipakai serta kriteria pencapaian kompetensi. Dalam mengamalkan penilaian autentik pendidik menyusun instrumen dan rubrik penilaian autentik sesuai dengan kapabilitas yang akan dinilai. Pada kompetensi sikap pendidik mengerjakan evaluasi melalui 5 teknik penilaian yaitu observasi atau pengamatan, penilaian diri, penilaian teman sejawat, jurnal, dan wawancara. Teknik yang diamalkan dalam penilaian autentik pada kompetensi pengetahuan meliputi tes tulis, tes lisan, dan penugasan atau proyek. Sedangkan teknik penilaian yang diamalkan pada kompetensi keterampilan adalah penilaian kinerja, penilaian proyek, penilaian produk, dan penilaian portofolio.

Instrumen penilaian harus melengkapi kualifikasi yang ada yaitu, mempresentasikan atau menjabarkan kapabilitas yang akan dinilai, penyusunan evaluasi harus melengkapi persyaratan teknis yang sesuai dengan rangka instrumen yang dibuat, dan penggunaan bahasa yang benar dan baik serta komunikatif sesuai perkembangan pebelajar (Ani, 2013). Penilaian pembelajaran dan Rencana Pelaksanaan Pembelajaran (RPP) merupakan kesatuan yang saling menguatkan dan saling terikat. Sehingga ketika guru membuat RPP atau Rencana Pelaksanaan Pembelajaran harus dibuat pula perencanaan penilaian pembelajaran yang mencakup instrumen penilaian (Sya'idah et al., 2016). Menurut Kunandar (2015:83) dalam membuat penilaian karakteristik instrumen harus diperhatikan dengan baik, karakteristik instrumen yang baik meliputi valid, reliabel, representative, praktis, diskriminatif, spesifik dan proporsional.

\section{Pelaksanaan Penilaian Autentik}

Setelah menyusun perencanaan penilaian autentik, guru menerapkan penilaian autentik sesuai dengan perencanaan yang telah dirancang sebelumnya. Pelaksanaan penilaian autentik juga disamakan dengan kompetensi yang akan dinilai. Menurut Kunandar (2015:73-74) terdapat standar dalam penerapan penilaian bahwa pengajar melakukan kegiatan evaluasi sesuai dengan tata cara penilaian yang telah dirangkai pada awal aktivitas pembelajaran. Menurut (Divanda et al., 2019) bahwa penilaian autentik adalah suatu formasi penilaian dimana pebelajar harus mampu menerapkan konsep atau teori edukasi yang sudah diperoleh di sekolah untuk dapat diterapkan dalam kehidupan sehari-hari. Hal ini juga diperkuat menurut (Nurhayati \& Ahmad, 2018) penilaian autentik berbeda dengan penilaian tradisional. Penilaian tradisional kemampuan berpikir anak didik yang dinilai cenderung pada tingkat memahami dan berfokus pada guru. Sedangkan pada penilaian autentik kemampuan berpikir pebelajar yang dinilai adalah level penerapan dan berfokus kepada pebelajar. Penilaian autentik menuntut pebelajar memperagakan pengetahuan, dan keterampilan yang telah didapatkan, pebelajar juga harus 
dapat menciptakan jawaban atau hasil ciptaan yang didasari oleh pengetahuan teoritis. Dengan demikian, pebelajar akan merasakan bahwa edukasi yang diperbuat dan dirasakannya menjadi lebih berfaedah (Astriyandi et al., 2016).

Berdasarkan salah satu fungsi penilaian autentik dalam pembelajaran menurut Masnur Muslich (2011) dalam (Chusnia et al., 2017) bahwa penilaian autentik penting posisinya dalam memajukan mutu pada aktivitas pembelajaran. Pendidik dapat mengetahui pula kemampuan-kemampuan yang belum dikuasai dan yang sudah dikuasi oleh pebelajar. Pada penerapan penilaian pengetahuan verbal dan pengetahuan prosedural yang diperbuat dilandaskan pada tujuan instruksional yaitu menerapkan dasardasar penilaian dalam kelas, membangun dan mengelola berbagai bentuk penilaian kelas, melakukan analisis, menjelaskan bentuk evaluasi dalam kelas yang lainnya, serta mengidentifikasi perkembangan tren terbaru pada persoalan yang terjadi saat ini dalam pengujian dan penilaian (Fook \& Sidhu, 2010).

Implementasi pada penilaian autentik terdiri dari 3 bagian yaitu, mendesain penilaian autentik, mengimplementasikan atau melaksanakannya, memberikan hasil atau skor pada produk pebelajar dan memberikannya timbal balik kepada pebelajar. Dari hasil pengamatan kelas, pendidik melaksanakan pengembangan professional pada penilaian autentik berdasarkan contoh-contoh karya pebelajar yang dikumpulkan (Rukmini \& Saputri, 2017). Penilaian autentik mengharuskan pebelajar mengerjakan beragam tugas yang merefleksikan pengutamaan dan tantangan yang terdapat dalam aktivitas pembelajaran (Wiggins, 1991). Pada penilaian autentik, penguasaan terhadap rancangan atau materi pembelajaran juga dinilai (Palm, 2008).

\section{Kendala yang dihadapi Guru dalam Penilaian Autentik}

Penilaian autentik selaras untuk menilai kompetensi pebelajar terutama pada aspek keterampilanya, tetapi belum semua pendidik cakap tentang cara melaksanakan penilaian autentik. Kesulitan yang paling banyak dirasakan oleh pengajar adalah pemahaman tentang KI dan KD. Pendidik kesulitan mengimplementasikan penilaian secara sekaligus ketika aktivitas edukasi berjalan. Pada pengertian penilaian autentik pendidik hanya sekedar memahami, tetapi untuk melaksanakan dan menyesuaikan dengan syarat kurikulum 2013 masih terdapat kerancuan (Bakti et al., 2014). Dalam penerapan penilaian autentik siswa diwajibkan untuk menghimpun petunjuk dengan pendekatan saintifik. Dengan memahami aneka fenomena yang terjadi serta gejala dan hubungannya satu sama lain, serta mengaitkan apa yang telah dipelajari di sekolah dengan kehidupan di luar sekolah (Komarudin et al., 2019).

Kendala yang dirasakan oleh para narasumber pada saat mengimplementasikan penilaian autentik dalam kompetensi sikap adalah kurangnya keterbukaan siswa ketika dilakukan sesi wawancara dan penilaian teman sejawat, waktu dalam menerapkan penilaian yang kurang, kemampuan pengajar yang kurang dalam mengamati setiap pebelajar dalam waktu bersamaan dikarenakan jumlah pebelajar yang banyak, serta kendala ketika membuat rubrik penilaian. Menurut Kunandar (2015) kelemahan dalam penilaian kompetensi sikap yang banyak dirasakan oleh pengajar adalah sulitnya menerapkan penilaian dikarenakan banyaknya jumlah siswa. Oleh karena itu, kelemahan-kelemahan yang ada saat menerapkan penilaian kompetensi sikap perlu diperhatikan dengan seksama, sehingga penilaian yang diterapkan tidak menyebabkan bias pada hasil penilaian kompetensi sikap. Pada implementasi penilaian autentik kompetensi pengetahuan kendala yang dirasakan oleh para pengajar adalah kurangnya antusias pebelajar dalam belajar, perlu banyaknya waktu dalam pengerjaan kisi-kisi soal maupun pada saat penilaian, hasil atau nilai yang dihasilkan pebelajar tidak sesuai dengan kemampuan, karena banyaknya kebijakankebijakan tambahan dari sekolah, serta keadaan yang dialami pebelajar dalam belajar ketika menafsirkan materi dengan daya penyerapan setiap pebelajar berbeda-beda. Gambaran dalam perkembangan belajar pebelajar perlu dipahami oleh pengajar agar bisa memastikan bahwa pebelajar mengikuti aktivitas edukasi yang benar (Kunandar:2015). 
Kendala yang dirasakan oleh para pengajar dalam implementasi penilaian autentik pada kompetensi keterampilan yaitu kurangnya ketersediaan pebelajar untuk membuat tugas-tugas yang sudah diberikan, kurangnya waktu dan alokasi biaya yang kurang dalam pembuatan format penilaian dan pada proses pelaksanaan, cukup sulit dalam pembuatan indikator untuk instrumen penilaian keterampilan, perlunya subjektivitas pengajar dalam menilai keterampilan para pebelajar, serta setiap pebelajar memiliki kapabilitas yang berbeda-beda, sehingga saat aktivitas edukasi perlu adanya kontrol secara intens untuk mengamati hasil pencapaian dari setiap anak didik. Dalam menerapkan penilaian kompetensi keterampilan hendaknya mencermati karakteristik dari tiap cara penilaian kompetensi keterampilan, hingga dapat meminimalisir kelemahan-kelemahan dan kesulitan yang dihadapi oleh pengajar dalam melakukan penilaian keterampilan (Kunandar:2015). Hal ini juga diperkuat dengan teori yang dikemukakan oleh Majid (2015) bahwa pendidik harus menyediakan alternatif rencana edukasi bagi pebelajar yang mengalami kesulitan.

\section{SIMPULAN}

Pendidik mata pelajaran umum (meliputi mata pelajaran IPA, IPS, Matematika, dan Bahasa Indonesia) pada jenjang SMP sudah memahami penilaian autentik secara baik. Secara teori para pengajar telah mengerti secara jelas terkait pemahaman awal penilaian autentik. Tetapi dalam praktiknya masih ada beberapa pengajar yang belum melaksanakan secara sempurna terkait perumusan RPP dan korelasinya dengan penilaian autentik. Dalam prosedur perencanaan penilaian autentik secara teori para pengajar sudah memahami dengan benar dan baik bagaimana proses perencanaan dalam menerapkan penilaian autentik yang benar, tetapi dalam praktiknya masih banyak pengajar yang kesulitan dalam membuat rubrik yang sesuai dengan kompetensi yang akan dinilai. Pelaksanaan yang diterapkan oeh para pengajar yang paling banyak sudah dilakukan dengan baik dan benar adalah penilaian kompetensi pengetahuan, karena pengajar lebih profesional dan lebih memahami konsep dasar tentang penilaian kompetensi pengetahuan. Sedangkan pada penerapan penilaian autentik pada kompetensi sikap dan kompetensi keterampilan masih banyak pengajar yang merasa kesulitan melaksanakannya.

Kendala-kendala yang dihadapi pendidik mulai dari proses perencanaan, pelaksanaan, hingga hasil pada penilaian autentik meliputi kompetensi sikap, pengetahuan, dan keterampilan adalah waktu dalam mengamalkan penilaian yang kurang, kurangnya sarana dan prasarana yang memadai untuk memudahkan pendidik mengakses dan mengamalkan penilaian autentik, hasil atau nilai yang didapatkan oleh pebelajar tidak sesuai dengan kapabilitas pebelajar, karena ada banyaknya kebijakan-kebijakan tambahan dari sekolah, kondisi yang dialami pebelajar dalam belajar ketika mengasumsikan materi dengan daya penyerapan setiap pebelajar berbeda-beda serta kemampuan yang berbeda-beda, sehingga saat aktivitas pembelajaran perlu ada kontrol secara intens untuk mengetahui hasil pencapaian dari setiap pebelajar, kapabilitas pengajar yang kurang dalam mengamati setiap pebelajar dalam durasi bersamaan dikarenakan jumlah pebelajar yang banyak, hingga kendala ketika membuat rubrik penilaian.

\section{DAFTAR RUJUKAN}

Ani, Y. (2013). Penilaian Autentik Dalam Kurikulum 2013. Seminar Nasional Implementasi Kurikulum $2013,742-749$.

Astriyandi, A., Chotimah, U., \& Faisal, E. El. (2016). Kemampuan guru menerapkan penilaian autentik dalam pembelajaran ppkn. Jurnal Bhineka Tunggal Ika, 3(2), 187-198.

Bakti, A. S., Kusairi, S., \& Muhardjito. (2014). Pengembangan Penilaian Autentik Berbasis Kurikulum 2013. Jurnal Forum Penelitian, 1(1), 1-12.

Chusnia, S., Sa'dijah, C., \& Harsati, T. (2017). Analisis kebutuhan instrumen asesmen autentik dalam pembelajaran matematika di sekolah dasar. 462-470.

Divanda, A. D., Suwandi, S., \& Hastuti, S. (2019). Implementasi Penilaian Autentik Dalam Kurikulum 2013 Pada Pembelajaran Bahasa Indonesia (Studi Kasus Di Sma Negeri 1 Gemolong). Basastra: Jurnal Bahasa, Sastra, Dan Pengajarannya, $\quad 6(2), \quad 1$. https://doi.org/10.20961/basastra.v6i2.37659 
Ermawati, S., \& Taufiq, H. (2017). Penilaian Autentik dan Relevansinya dengan Kualitas Hasil Pembelajaran (Persepsi Dosen dan Mahasiswa IKIP PGRI Bojonegoro). Jurnal Pendidikan Ilmu Sosial, 27(1), 92-103.

Fook, C. Y., \& Sidhu, G. K. (2010). Authentic Assessment and Pedagogical Strategies in Higher Education. Journal of Social Sciences, 6(2), 153-161. https://doi.org/10.3844/jssp.2010.153.161

Komarudin, K., Sarkadi, S., \& Alkhudri, A. T. (2019). Peningkatan Kompetensi Guru PPKN SMP Dalam Melaksanakan Penilaian Autentik Berdasarkan Kurikulum 2013. Sarwahita, 15(02), 119130. https://doi.org/10.21009/sarwahita.152.07

Kunandar. (2015). Penilaian Autentik (Pendekatan Hasil Belajar Peserta Didik Berdasarkan Kurikulum 2013) Suatu Pendekatan Praktis Disertai dengan Contoh. Jakarta: Rajawali Pers.

Kusmijati, N. (2014). Penerapan Penilaian Autentik Sebagai Upaya Memotivasi Belajar Peserta Didik. Prosiding Seminar Nasional Hasil - Hasil Penelitian Dan Pengabdian LPPM UMP 2014, 55-62.

Majid, Abdul. (2015). Penilaian Autentik Proses dan Hasil Belajar. Bandung: PT Remaja Rosdakarya.

Meliana, S., Utami, E. S., \& Sukoyo, J. (2019). PENGEMBANGAN PENILAIAN AUTENTIK PEMBELAJARAN TEKS DIALOG BAHASA JAWA KELAS VII. Piwulang:Journal of Javanese Learning and Teaching, 7(2), 44-52.

Menteri Pendidikan dan Kebudayaan RI. (2013). Peraturan Menteri Pendidikan dan Kebudayaan Nomor 68 Tahun 2013 Tentang Kerangka Dasar dan Struktur Kurikulum Sekolah Menengah Pertama/Madrasah Tsanawiyah. 21(1), 1-9. https://doi.org/10.1016/j.solener.2019.02.027

Menteri Pendidikan dan Kebudayaan RI. (2013). Permendikbud No 66 Tahun 2013 tentang Standar Penilaian Pendidikan. 2011, 1-6. https://doi.org/10.1016/j.metabol.2009.10.012

Menteri Pendidikan dan Kebudayaan RI. (2013). Permendikbud Nomor 65 Tahun 2013 Tentang Satndar Proses. 2011, 1-13.

Nurhayati, E., \& Ahmad, T. A. (2018). Implementasi Penilaian Autentik dalam Pembelajaran Sejarah di SMA Negeri 1 Semarang. Indonesian Journal of History Education, 6(1), 21-30.

Palm, T. (2008). Performance assessment and authentic assessment: A conceptual analysis of the literature. Practical Assessment, Research and Evaluation, 13(4), 1-11.

Poerwati, L.E, \& Amri,S. (2013). Panduan Memahami Kurikulum 2013. Jakarta: PT Prestasi Pustakarya.

Rahman, S. A., \& Romdhani, M. (2015). Persepsi Guru Terhadap Penilaian Autentik. Jurnal Sekolah Dasar, 24(2), 151-160. http://journal2.um.ac.id/index.php/sd/article/view/1356

Ristanto, R. H., \& Djamahar, R. (2019). Penguatan Keterampilan Penilaian Autentik Guru IPA Biologi di Kabupaten Bogor. BAKTIMAS: Jurnal Pengabdian Pada Masyarakat, 1(1), 61. https://doi.org/10.32672/btm.v1i1.1183

Rukmini, D., \& Saputri, L. A. D. E. (2017). The authentic assessment to measure students' English productive skills based on 2013 Curriculum. Indonesian Journal of Applied Linguistics, 7(2), 263-273. https://doi.org/10.17509/ijal.v7i2.8128

Sya'idah, U., Amaliyah, A., \& Ismail, Y. (2016). Kemampuan Guru PAI dalam Merencanakan dan Melaksanakan Penilaian Autentik. Jurnal Online Studi Al-Qur'an, 12(2), 143-157. https://doi.org/10.21009/jsq.012.2.01

Wajdi, F. (2017). Implementasi Project Based Learning (Pbl) Dan Penilaian Autentik Dalam Pembelajaran Drama Indonesia. Jurnal Pendidikan Bahasa Dan Sastra, 17(1), 86. https://doi.org/10.17509/bs_jpbsp.v17i1.6960

Wiggins, G. (1991). The case for authentic assessment. Practical Assessment, Research and Evaluation, 2(2), 1990-1991.

Wildan, W. (2017). Pelaksanaan Penilaian Autentik Aspek Pengetahuan, Sikap Dan Keterampilan Di Sekolah Atau Madrasah. Jurnal Tatsqif, 15(2), 131-153. https://doi.org/10.20414/jtq.v15i2.3 